\title{
ПРО ДІЯЛЬНІСТЬ ВІДДІЛУ ПОЧАТКОВОЇ ОСВІТИ ІНСТИТУТУ ПЕДАГОГІКИ НАПН УКРАЇНИ ЩОДО РЕАЛІЗАЦІЇ ДЕРЖАВНОГО СТАНДАРТУ ПОЧАТКОВОЇ ОСВІТИ
}

\section{https://doi.org/10.37472/2707-305X-2020-2-1-8-2}

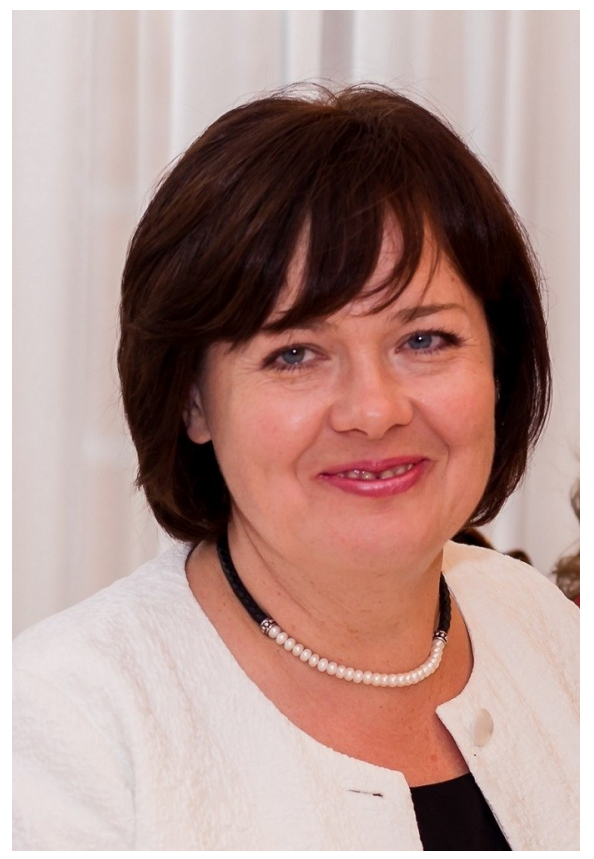

ОНОПРІЕНКО

\section{Оксана Володимирівна}

кандидат педагогічних наук, старший науковий співробітник, завідувач відділу початкової освіти Iнституту педагогіки Національної академії педагогічних наук України, м. Київ, Україна

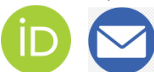

Анотація. Розкрито основні напрями діяльності вчених відділу початкової освіти Інституту педагогіки Начіональної академії педагогічних наук України, пов'язаної із запровадженням Концепиії реалізації державної політики у сфері ресрормування загальної середньої освіти «Нова українська школа», зокрема - Державного стандарту початкової освіти. Зазначено, що наукові прачівники відділу: створювали нормативні документи для початкової школи Державний стандарт, типові освітні програми; розробили методичні рекомендації щодо викладання навчальних предметів в умовах Нової української школи; створили підручники з української мови і читання, математики, курсу «Я досліджую світ» для 1, 2 і 3 класів; популяризують наукові розробки на освітянських заходах, у науковометодичних публікаціях. Розкрито роль вчених відділу у всеукраїнському експерименті з пілотування Державного стандарту, зокрема - про навчальне і методичне забезпечення уроків математики в експериментальних класах. Надано інформацію про проведені в Інституті педагогіки НАПН України курси за програмою підвищення кваліфікації педагогічних і науково-педагогічних працівників "Методика формування математичної компетентності учнів початкової школи». Окремим напрямом діяльності стала підтримка вчителів та учнів в умовах дистанційного навчання під час карантину.

Ключові слова: початкова освіта; типова освітня програма; дидактико-методичний супровід; навчально-методичне забезпечення початкової школи.

Від 2017 р. у нашій країні запроваджується Концепція реалізації державної політики у сфері реформування загальної середньої освіти «Нова українська школа». До цього процесу активно долучені вчені відділу початкової освіти Інституту педагогіки НАПН України (далі - відділ). Робота розгортається за кількома напрямами.

1. Нормотворча діяльність. У складі робочих груп МОН України наукові працівники відділу створювали Державний стандарт початкової освіти за мовно-літературною, математичною, природничою, соціальною, здоров'язбережувальною, громадянською та історичною галузями. Під керівництвом академіка НАПН України О.Я. Савченко відділ розробив типові освітні програми для 1-2 і 3-4 класів закладів загальної середньої освіти (МОН України, 2019а; МОН України, 2019b). Згідно з даними Інституту освітньої аналітики МОН України, за цими програмами навчається понад $55 \%$ учнів Нової української школи, а рівень їхньої освітньої підготовки на 15 \% вищий, ніж у тих, хто навчається за альтернативною освітньою програмою. Вчені відділу у співпраці з практиками та освітніми експертами розробили нові підходи до оцінювання освітніх результатів учнів початкової школи на основі системи 


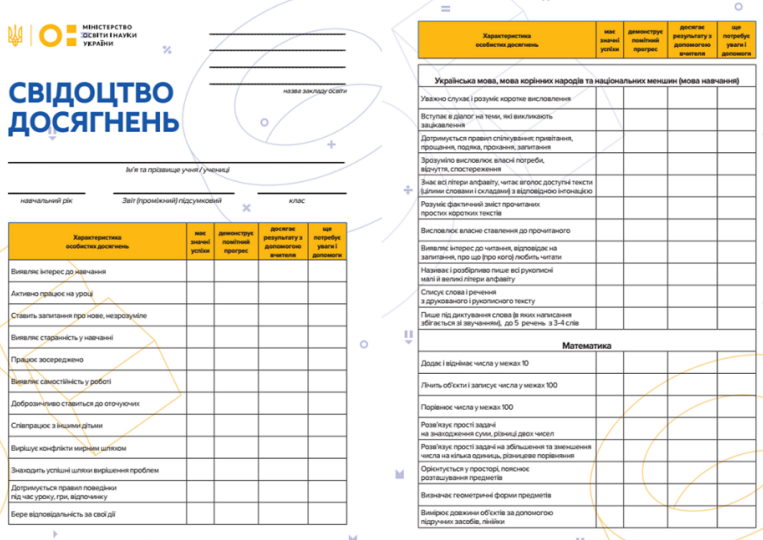

показників особистісних і навчальних досягнень, які конкретизовано в документі «Свідоцтво досягнень учнів 1 класу» (МОН України, 2018), що нині впроваджено в масову шкільну практику.

2. Методичне забезпечення початкової школи. Два роки поспіль розроблялися та були випущені методичні рекомендації щодо викладання навчальних предметів у перших і других класах закладів освіти (Савченко та ін., 2018; Топузов та ін., 2018). У 2020-2021 навчальному році вперше за програмами НУШ будуть навчатися учні третіх класів. Для учителів підготовлено методичні рекомендації з упровадження типових освітніх програм для другого циклу навчання та поради авторів підручників, які забезпечують досягнення очікуваних результатів програми .

3. Навчальне забезпечення НУШ. Наукові працівники відділу стали авторами та співавторами підручників і навчальних посібників з української мови (К.І. Пономарьова, О.Я. Савченко, О.В. Вашуленко, О.М. Петрук, В.О. Мартиненко, О.Ю. Прищепа); математики (О.В. Онопрієнко, Н.П.Листопад) і курсу «Я досліджую світ» (Н.М. Бібік, І.В. Андрусенко), які перемогли у всеукраїнських конкурсах проєктів підручників у

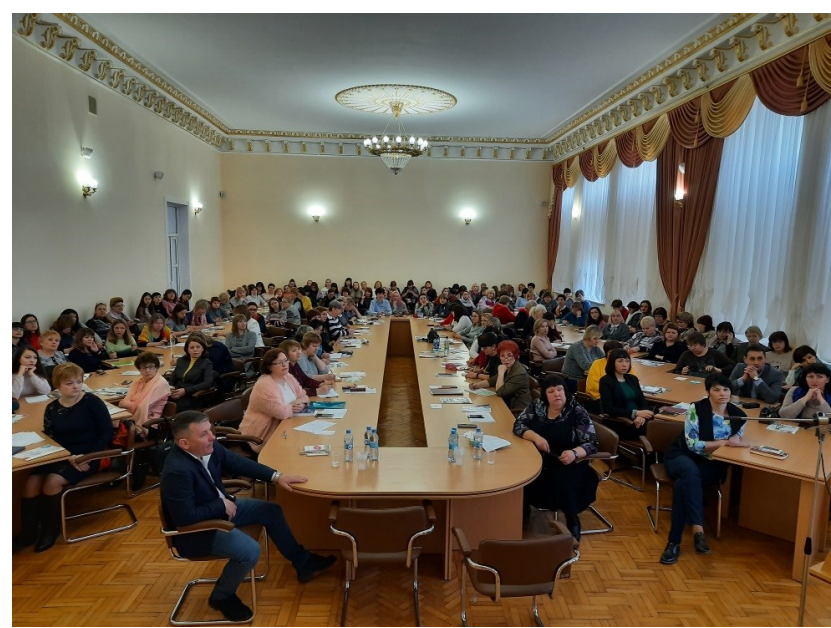

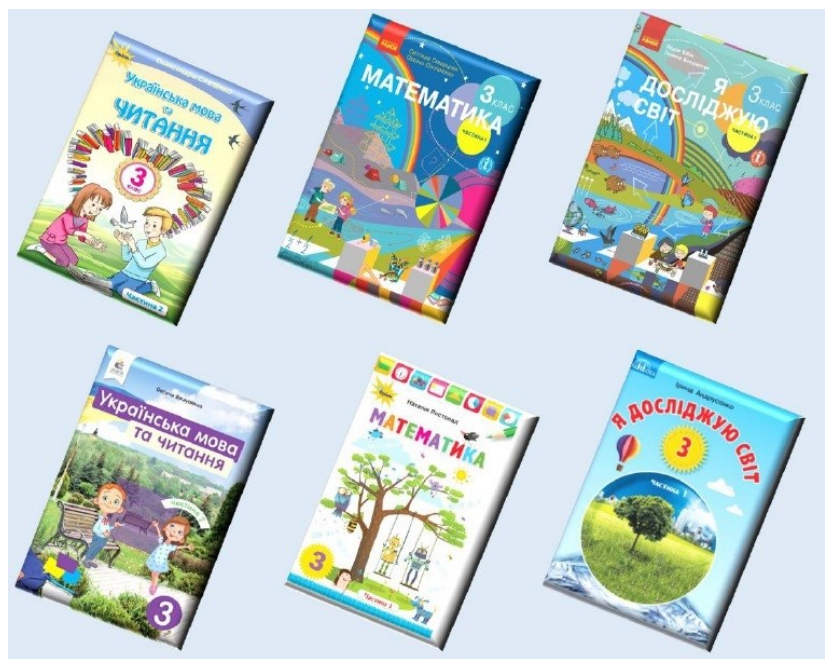

2018, 2019, 2020 рр. і друкуються за державні кошти. Підручники третій рік поспіль лідирують за кількістю вибору вчителями країни. Так, за підручниками вчених відділу в третьому класі навчатимуться українській мові та читанню понад 233 тис. учнів, математики - понад 276 тис., курсу «Я досліджую світ» - майже 104 тис. учнів.

4. Просвітницька діяльність. Відділ започаткував і реалізовує постійно діючий семінар «Дидактико-методичний супровід компетентнісно орієнтованого навчання молодших школярів». За два роки функціонування НУШ для допомоги вчителям відділ провів 36 науково-практичних семінарів, сім науково-методичних платформ, чотири всеукраїнські вебінари, численні круглі столи, майстер-класи та інші заходи.

3 метою дидактико-методичного супроводу реалізації типової освітньої програми, розробленої під керівництвом О.Я. Савченко, опубліковано в педагогічних журналах і розміщено в Електронній бібліотеці НАПН України 32 наукові та науковометодичні статті; підготовлено й розміщено в Електронній бібліотеці Інституту педагогіки НАПН України шість планових методичних посібників:

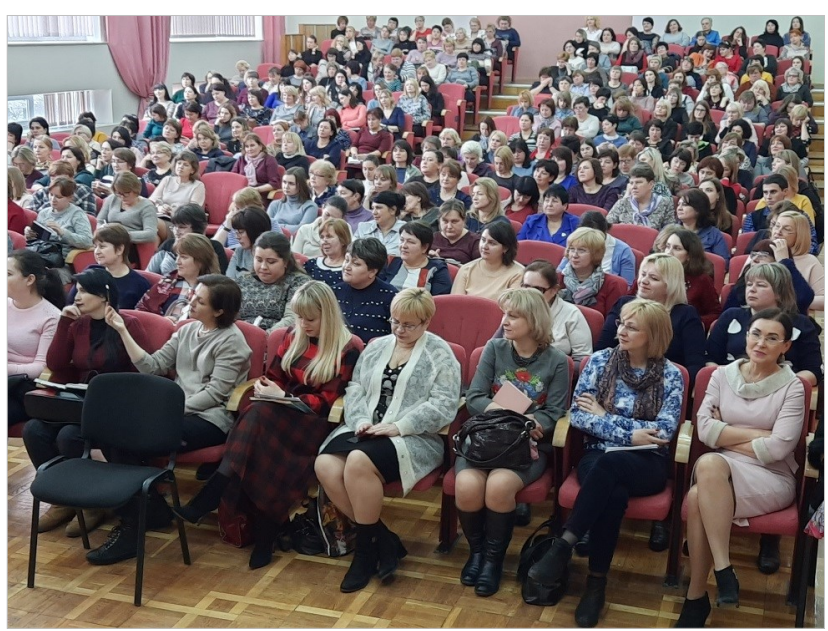




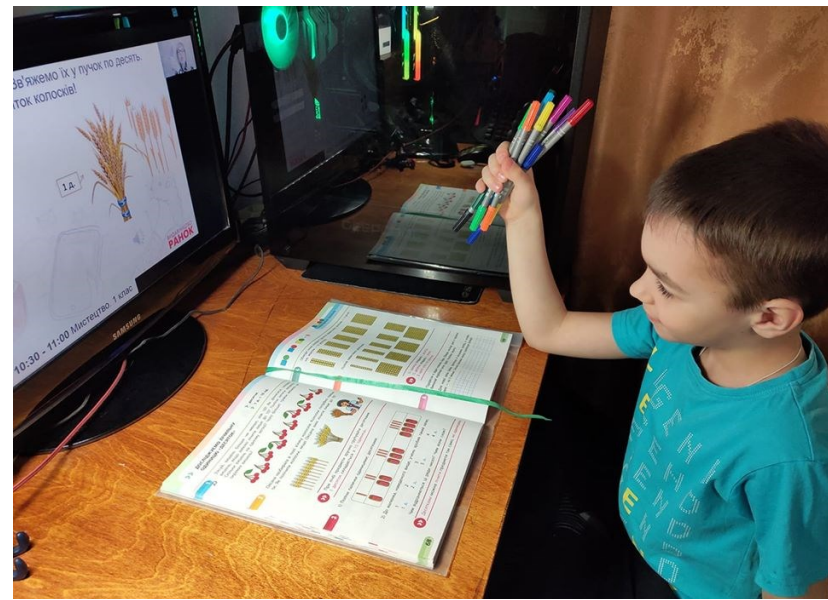

- «Система міжпредметних завдань на уроках з літературного читання» (О.Я. Савченко);

- «Соціалізація молодших школярів у взаємозв'язку урочної та позаурочної діяльності» (Н.М. Бібік);

- «Формування комунікативної компетентності молодших школярів у процесі навчання української мови» (К.І. Пономарьова);

- «Індивідуальний підхід до формування і розвитку навички читання молодших школярів» (В.О. Мартиненко);

- «ннструментарій оцінювання результатів компетентнісно орієнтованого навчання молодших школярів» (О.В. Онопрієнко);

- «Формування і розвиток навичок письма молодших школярів на засадах диференційованого підходу» (О.Ю. Прищепа) (Інститут педагогіки НАПН України, n.d.a).

5. Експериментальна діяльність. Відповідно до плану заходів із запровадження Концепції «Нова українська школа» (Кабінет Міністрів України, 2017) з 2017/2018 навчального року відбувається всеукраїнський експеримент «Розроблення і впровадження навчально-методичного забезпечення початкової освіти в умовах реалізації нового Державного стандарту початкової освіти» на базі загальноосвітніх навчальних закладів (МОН України, 2017). Відділ також активно долучений до цього експерименту. Зокрема, Н.М. Бібік і О.В. Онопрієнко призначені науковими консультантами експерименту; Н.М. Бібік, К.І. Пономарьова, Н.П. Листопад запропонували пілотним першим класам навчально-методичне забезпечення до уроків української мови, математики, інтегрованого курсу «Я досліджую світ»; О.В. Онопрієнко у співавторстві з завідувачкою кафедри Південноукраїнського державного педагогічного університету ім. К.Д. Ушинського С.О. Скворцовою упродовж трьох років надають навчальні та методичні розробки з математики, здійснюють систематичне консультування учителів-експериментаторів.

6. Курсова підготовка вчителів початкової школи. В Інституті педагогіки НАПН України у 2020 р. вперше проведено ліцензовані курси за програмою підвищення кваліфікації педагогічних і науково-педагогічних працівників за спеціальністю «013 Початкова освіта» - «Методика форму вання математичної компетентності учнів початкової школи», розробленою С.О.Скворцовою О.В. Онопрієнко (Інститут педагогіки НАПН України, n.d.b). Науковці разом зі слухачами курсів опрацювали технологію реалізації авторської методичної системи, що спирається на дані досліджень вікової психології і нейропсихології про навчальні та поведінкові характеристики дітей, які постійно користуються новітніми цифровими пристроями. До цієї роботи було залучено доктора психологічних наук, провідного наукового співробітника Інституту психології ім. Г.С. Костюка НАПН України Л.О. Кондратенко, разом із якою розглянуто особливості розвитку пізнавальних процесів у сучасних молодших школярів. Увагу в очній частині курсів присвятили методиці роботи над сюжетними задачами та організації навчальних досліджень на уроках математики. Опрацьовані матеріали дають змогу учасникам курсів на якісно новому рівні забезпечити методичний супровід навчання молодших школярів математики з урахуванням їхніх психологічних особливостей.

Події у країні, пов'язані із запровадженням карантину, внесли корективи і в роботу відділу початкової освіти. Науковим працівникам довелося швидко реагувати на складні обставини й вчасно зорганізуватися для підтримки учителів та учнів в умовах дистанційного навчання. Серед запроваджених заходів - щоденне консультування учителів, які на волонтерських засадах

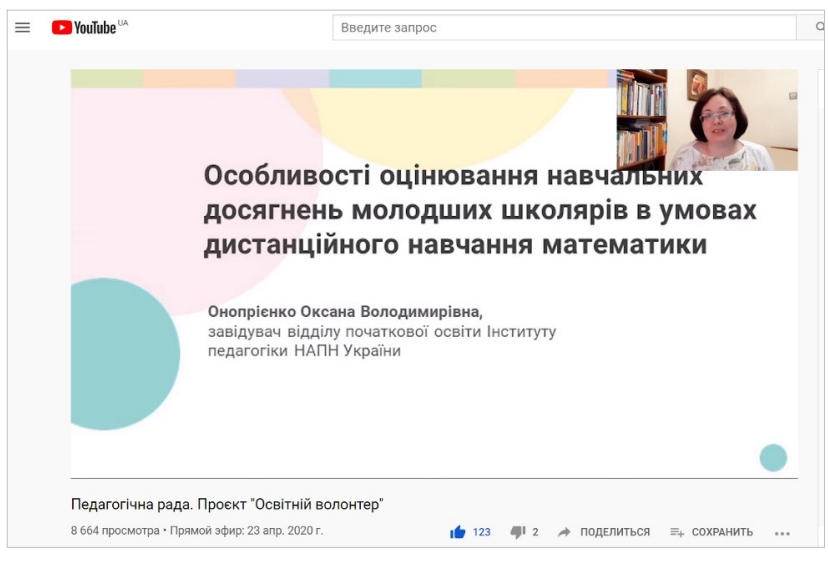


проводять уроки онлайн за підручниками, створеними вченими відділу початкової освіти Інституту педагогіки НАПН України; надання матеріалів для домашнього навчання; розроблення робіт для підсумкового контролю навчальних досягнень учнів тощо. Нині триває робота над підготовкою завдань для вхідної діагностики навченості учнів 2-5 класів на початку наступного навчального року. Це допоможе зібрати необхідні відомості про здобутий на попередньому етапі навчання рівень досягнень та забезпечити умови, необхідні для планування подальшої освітньої діяльності та визначення напрямів взаємодії 3 учнями та їхніми батьками.

\section{СПИСОК ВИКОРИСТАНИХ ДЖЕРЕЛ}

Електронна бібліотека НАПН України. (n.d.). Відділ початкової освіти Інституту педагогіки НАПН України. https://lib.iitta.gov.ua/view/divisions/ped/

Інститут педагогіки НАПН України. (n.d.a). Електронна бібліотека. http://undip.org.ua/news/library/

Інститут педагогіки НАПН України. (n.d.b). Підвищення кваліфрікації педагогічних та науково-педагогічних працівників закладів освіти. http://undip.org.ua/ info/9580/

Кабінет Міністрів України. (2017, 13 грудня). Про затвердження плану заходів на 2017-2029 роки із запровадження Концепиії реалізації державної політики у сфрері реформування загальної середньої освіти «Нова українська школа» (903-р). https://zakon.rada.gov.ua/laws/show/903-2017-p

Міністерство освіти і науки України. (2017, 13 липня). Про проведення всеукраїнського експерименту на базі загальноосвітніх навчальних закладів (1028). https://osvita.ua/legislation/Ser_osv/56646/

Міністерство освіти і науки України. (2018, 20 серпня). Про затвердження методичних рекомендацій щодо оцінювання навчальних досягнень учнів першого класу у Новій українській школі (924). https://mon.gov.ua/ua/osvita/zagalna-serednyaosvita/nova-ukrayinska-shkola/ocinyuvannya

Міністерство освіти і науки України. (2019а, 8 жовтня). Про затвердження типових освітніх програм для 1-2 класів закладів загальної середньої освіти (1272). https://mon.gov.ua/ua/npa/pro-zatverdzhennyatipovih-osvitnih-program-dlya-1-2-klasiv-zakladivzagalnoyi-serednoyi-osviti

Міністерство освіти і науки України. (2019b, 8 жовтня). Про затвердження типових освітніх програм для 3-4 класів закладів загальної середньої освіти (1273). https://mon.gov.ua/ua/npa/pro-zatverdzhennyatipovih-osvitnih-program-dlya-3-4-klasiv-zakladivzagalnoyi-serednoyi-osviti-1273

Онопрієнко, О.В. (2020, 23 квітня). Особливості очінювання навчальних досягнень молодших школярів в умовах дистанційного навчання математики [Відео]. Проєкт «Освітній волонтер». http://undip.org.ua/info/9899/

Савченко, О.Я., Бібік, Н.М., Вашуленко, М.С., Онопрієнко, О.В., Мартиненко, В.О., Пономарьова, К.І., Прищепа, О.Ю., Листопад, Н.П., Вашуленко, О.В., \& Андрусенко, І.В. (2018). Методичні рекомендації для організації освітнього процесу в початкових класах закладів загальної середньої освіти у 2018/2019 навчальному рочі. Київ: Інститут педагогіки НАПН України. https://lib.iitta.gov.ua/714257/

Топузов, О.М., Савченко, О.Я., Бібік, Н.М., Вашуленко, М.С., Онопрієнко, О.В., Мартиненко, В.О., Пономарьова, К.І., Прищепа, О.Ю., Листопад, Н.П., Вашуленко, О.В., \& Андрусенко, І.В. (2018). Початкова освіта : Методичні рекомендації щодо використання в освітньому процесі Типової освітньої програми для 2 класів закладів загальної середньої освіти. Типова освітня програма для закладів загальної середньої освіти. Київ: Інститут педагогіки НАПН України. https://lib.iitta.gov.ua/716946/

\title{
ON THE ACTIVITY OF THE DEPARTMENT OF PRIMARY EDUCATION OF THE INSTITUTE OF PEDAGOGY OF THE NATIONAL ACADEMY OF EDUCATIONAL SCIENCES OF UKRAINE REGARDING THE IMPLEMENTATION OF THE STATE STANDARD FOR PRIMARY EDUCATION
}

\author{
PhD in Pedagogy, Senior Researcher, Head of the Department of Primary Education, \\ Institute of Pedagogy of the National Academy of Educational Sciences of Ukraine, Kyiv, Ukraine
}

\begin{abstract}
The main directions of the Department of Primary Education at the Institute of Pedagogy of the National Academy of Educational Sciences of Ukraine researchers' activity are enlightened. This refers to the implementation of the Concept of State Policy in the field of General Secondary Education Reforming "The New Ukrainian School", in particular, the State Standard for Primary Education. It is noted that the Department's researchers have developed regulatory documents for primary school, i.e. the State Standard, typical education programs; methods recommendations for teaching subjects in the New Ukrainian School; textbooks in Ukrainian language and reading, mathematics, the course "I explore the world" for the 1st, 2nd and 3rd grades; the researchers popularise their research developments at the educational events, in the scientific and methodical publications. The role of the Department's researchers in the all-Ukrainian experiment on piloting the State Standard is analysed, in particular, on the educational and methodological support of mathematics lessons in experimental classes. The information on the courses taught at the Institute of Pedagogy of NAES of Ukraine within the program of in-service teacher training "Methods of Formation of Mathematical Competence of Primary School Pupils" is provided. The support of teachers and pupils under conditions of distance learning during COVID-19 quarantine was a separate area of activity.

Keywords: primary education; typical education program; didactic and methodical support; educational and methodological support of primary school.
\end{abstract}

Дата публікації: 19 травня 2020 р. 